MLM-3580(TR)

\title{
Photodecomposition of Energetic Nitro Compounds
}

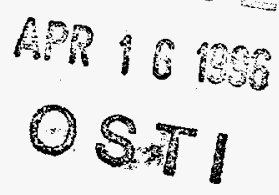

J. C. Mialocq

March 14, 1989

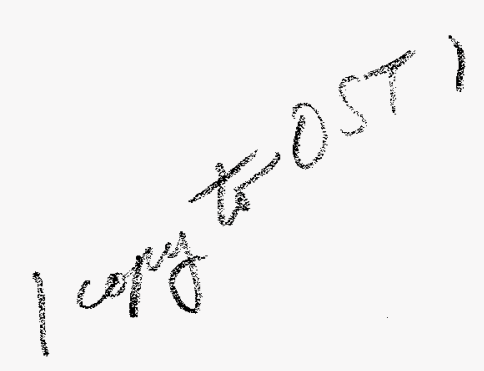

DSTRUBUTIU. ...... DO DOCMENT Is UNLMTEE

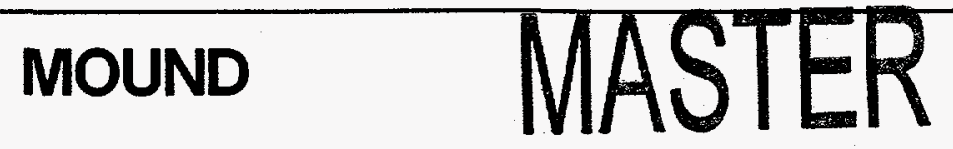

operated by

II EGRE MOUND APPLIED TECHNOLOGIES

P.O. Box 3000, Miamisburg, Ohio 45343-0987

for the

U. S. DEPARTMENT OF ENERGY

Contract No. DE-AC04-88DP43495 
MLM-3580(TR)

\title{
Photodecomposition of Energetic Nitro Compounds
}

\author{
J. C. Mialocq
}

March 14, 1989

Translated from Journal de Physique, 48:9, C4-163-C4-178 (1987).

\section{MOUND}

\author{
operated by \\ EGRE MOUND APPLIED TECHNOLOGIES \\ P.O. Box 3000, Miamisburg, Ohio 45343-0987 \\ for the \\ U. S. DEPARTMENT OF ENERGY
}

Contract No. DE-AC04-88DP43495 
Mialocq, J. C.: PHOTODECOMPOSITION OF ENERGETIC NITRO COMPOUNDS. (Photodécomposition des composés nitrés énergétiques.) Journal de Physique, Vo1. 48, No. 9 (supplement), Colloquium C4, Pp. C4-163 to C4-178, September 1987. CEN Saclay, IRDI, 91191 Gif-sur-Yvette, France.

\begin{abstract}
The photodecomposition of energetic nitrocompounds depends on the exeitation energy, the light intensity which determines the mono-, oi- or multipnotonic character of the initial process and their gaseous, liquid or solid state. The initial processes of the photodecomposition of nitromethane and nitroalcanes are reviewed and their relevance to the initiation of energic nitrocompounds detonation is discussed. The case of nitramines (dimethylnitramine and tetryl) is also oriefly introduced.
\end{abstract}

\title{
1. INTRODUCTION
}

The study of the photodecomposition of energetic molecules is useful

for understanding the mechanisms of initiation of the decomposition reactions of explosives at elevated temperature or under the effect of a shock wave. Monochromatic light excitation in effect makes it possible to bring the molecules from a known fundamental vibrational and electronic state to a well-defined excited vibration state whose development is, in principle, possible to describe. Understanding dissociation processes is more difficult in polyatomic molecules than in diatomic ones, however, because of the greater number of vibrational degrees of freedom. In addition, knowing that the excitation energy of a molecule is greater than the threshold of dissociation does not allow us to conclude that this molecule is going to dissociate, since we do not a priori know the coordinate of the reaction and how the eriergy will be exchanged between the vibration modes.

In this review, we shall attempt to present the recent significant results on the photodecomposition of some explosives. For example, the photolysis of 
nitromethane, the simplest member of the nitroparaffin family, is still not understood in spite of the many studies done since the historical works of Hirschlaff and Norrish [1]. The photolysis of other nitro compounds, among which we shall examine the case of nitramines, is also quite complex [2]

\section{PHOTODECOMPOSITION OF NITROMETHANE}

We shall distinguish the case of the gas phase, where the nitromethane molecule undergoes processes characteristics of the isolated molecule, and the case of the condensed phase, where the processes may be more complex.

\subsection{UV Photolys is of Gaseous Nitromethane}

Since $1936[1]$, studies on the continuous photolysis of nitromethane based on the analysis of the end products have generally led to comparisons with thermal decomposition. A number of reactions have been proposed as the primary process :

\subsubsection{Cleavage of the $\mathrm{C}-\mathrm{NO}_{2}$ Bond}

$$
\mathrm{CH}_{3} \mathrm{NO}_{2} \stackrel{\mathrm{H \nu}}{\longrightarrow} \mathrm{CH}_{3}+\mathrm{NO}_{2}
$$

Observing the formation of small amounts of methyl nitrite during the photolysis of nitromethane gas, Pimentel and Rollefson [3] concluded that there was cleavage of the $\mathrm{C}-\mathrm{NO}_{2}$ bond, followed by recombination into $\mathrm{CH}_{3} \mathrm{NO}_{2}$ * or $\mathrm{CH}_{3}$ ONO*, this latter then dissociating to yield $\mathrm{CH}_{3} \mathrm{O}$ and No radicals. The $\mathrm{C}-\mathrm{NO}_{2}$ cleavage had been proposed back in 1950 by Cottrell and Reid in the thermal decomposition of nitromethane [4]. This cleavage was subsequently considered the main primary process of the UV photolysis of nitromethane gas 
[5-22]. But rearrangement processes could be involved to a lesser extent. According to Honda et al. [11], at $313 \mathrm{ng}$ the quantum yield of Reaction (1) is 0.6 via the excited triplet stage $\left(n-\pi^{*}\right)$ with an energy greater than $3.4 \mathrm{eV}$. In addition, Spears and Brugge estimated the vibrational populations of the $\mathrm{NO}_{2}$ fragment in a laser-induced fluorescence (LIF) microsecond experiment, by exciting the nitromethane at $252.2 \mathrm{~nm}$ and the $\mathrm{NO}_{2}$ fragment at $505 \mathrm{~nm}$ [14]. IR chemiluminescence of the $\mathrm{NO}_{2}$ fragment showed them that the $v_{3}$ mode was highly excited [15]. According to Haugen and Steinmetz [16], the $\mathrm{NO}_{2}$ fragment does not form when nitromethane is excited at 249 nm in the $n \rightarrow \pi *$ transition, at low pressure and in a defocussed beam. $\mathrm{NO}_{2}$ appears, on the other hand, after excitation at $193 \mathrm{~nm}$ in the $\pi^{*} \pi^{*}$ transition. Likewise, the study by Kwok et al. [17] on the photodissociation of $\mathrm{CH}_{3} \mathrm{NO}_{2}$ at $266 \mathrm{~nm}$ in a molecular jet indicates that there is no dissociation in the absence of collision. Schoen et al. [18], moreover, analyzed the kinetics of $\mathrm{NO}_{2}$ formation and found that the dissociation is accomplished in less than five picoseconds, with a quantum yield of 0.70 at $264 \mathrm{~nm}$. At $193 \mathrm{~nm}$, the efficiency of the dissociation was amply confirmed, since the quantum yield is 1 in a molecular jet [19] and some of the internal energy of the fragments is the electronic energy of the excited state ${ }^{2} \mathrm{~B}_{2}$ of $\mathrm{NO}_{2} *$, observed in fluorescence $[19,20]$.

The law of conservation of energy in effect allows us to write the relation:

$$
E_{\text {avail }}=n \nu+E_{\text {int }}-D\left(R-N D_{Z}\right)=E_{E}+E_{T}+E_{V}+E_{R}
$$

where the avallable energy $E_{\text {avail }}$ is the sum of the energy of the excitation photon and of the internal energy of the molecule $E_{i n t}$, minus the dissociation energy of the $\mathrm{R}-\mathrm{NO}_{2}$ bond, $\mathrm{D}\left(\mathrm{R}-\mathrm{NO}_{2}\right)=60.1 \mathrm{kcals} / \mathrm{mol}$. The available energy 
includes the electronic, translational, vibrational, and rotational energies of the fragments that Buttler et al. were able to measure [20].

In addition, they demonstrated that the dissociation took place before the relaxation of $\mathrm{NO}_{2}$ by the alkyl group, since after light excitation localized on $\mathrm{NO}_{2}$, the fluorescence spectrum of $\mathrm{NO}_{2} *$ did not depend on the nature of the alkyl group [20].

In the vicinity of $266 \mathrm{~nm}$, the efficiency of dissociation becomes a source of conflict, with Buttler et al. [20] estimating that the quantum yield of dissociation was less than 0.03 in the study by Kwok et al. [17], while Nialocq and Stephenson $[24,25]$ found a yield of $(0.17 \pm 0.11)$ and showed that the dissociation yield did not depend on the nature of the alkyl group $\left(\mathrm{R}=\mathrm{CH}_{3}, \mathrm{C}_{2} \mathrm{H}_{5}, 1-\mathrm{C}_{3} \mathrm{H}_{7}\right.$ and $2-\mathrm{C}_{3} \mathrm{H}_{7}$. The dissociation kinetics $(<6 \mathrm{psec})$ that they observed, 1ike that obtained by Schoen et al. [18], is in agreement with the rate constant that they calculated according to the RRKM theory, within the limits of temporal resolution: $k=4.8 \times 10^{12} \mathrm{sec}^{-1}$, or $\tau=0.21 \mathrm{psec}$. Quite recently, Greenblatt et al. [26] did not observe the production of the $\mathrm{NO}_{2}$ fragment for a nitromethane excitation at $282 \mathrm{~nm}$. It therefore seews that a threshold of cleavage of the $\mathrm{C}-\mathrm{NO}_{2}$ bond is involved toward $38,000 \mathrm{~cm}^{-1}$ : we must take into account the energy of the excitation photon and the internal energy of the nitromethane, which is different in a cell and in a molecular jet. But other factors may play a role, such as the lower sensitivity of detection for $\mathrm{NO}_{2}$ than for $\mathrm{OH}$, which has been observed, moreover, in very low concentrations. We have summarized the quantum yields of $\mathrm{NO}_{2}$ formation in Table 1. 
TABLE 1. QUANTUM YIELDS OF FRAGMENT FORMATION

IN THE UV PHOTOLYSIS OF $\mathrm{CH}_{3} \mathrm{NO}_{2}$ GAS (IN \%).

\begin{tabular}{|c|c|c|c|}
\hline$\lambda(\mathrm{nm})$ & $\mathrm{NO}_{2}$ & $\mathrm{OH}$ & HENO \\
\hline $\begin{array}{l}313 \\
282 \\
266 \\
264 \\
193\end{array}$ & $\begin{array}{r}60[11] \\
0[26] \\
<\quad 3[20] \\
317 \pm 11)[25] \\
70[18] \\
100[19]\end{array}$ & $\begin{array}{r}0,5-2 *[26] \\
0,4: 27]\end{array}$ & $20[11]$ \\
\hline
\end{tabular}

*In nitroethane, nitropropane, and tert-nitrobutane.

\subsubsection{Intramolecular Rearrangements}

Intramolecular elimination reactions involve a ring with four or five sites [members?] in the case of nitromethane [1,8] and the higher nitroalkanes $[6,21]:$

$$
\stackrel{n \nu}{\longrightarrow} \mathrm{CH}_{2} \mathrm{O}+\mathrm{HON}
$$

This reaction, proposed in 1936 by Hirschlaff and Norrish, is no longer of more than historical interest, since it is HNO which is eliminated [8], in Reaction (3).

$$
\begin{aligned}
& \mathrm{CH}_{3} \mathrm{NO}_{2} \stackrel{\mathrm{h \nu}}{\longrightarrow} \mathrm{CH}_{2} \mathrm{O}+\mathrm{HNO} \\
& \mathrm{C}_{2} \mathrm{H}_{5} \mathrm{NO}_{2} \stackrel{\mathrm{h \nu}}{\longrightarrow} \mathrm{C}_{2} \mathrm{H}_{4}+\text { HONO }
\end{aligned}
$$

The appearance of the $\mathrm{OH}$ spectrum immediately after the excitation led Napier and Norrish to propose the photolysis of a nitromethane isomer [10]: 


$$
\mathrm{CH}_{2}=\dot{N} \nearrow_{\mathrm{OH}}^{\overline{0}} \stackrel{\mathrm{H \nu}}{\longrightarrow} \mathrm{CH}_{2} \mathrm{NO}+\mathrm{OH}
$$

The quantum yield of Reaction (3) would be 0.2 at $313 \mathrm{~nm}$ according to Honda et al. [11], via the lowest excited singlet state $(n-\pi *)$.

Wittig et al. [21] showed that 2-nitropropane excited at 222, 249, or 308 $\mathrm{nm}$ yielded $\mathrm{OH}$ radicals as well as the more important nitrous acid radical HONO, via a five-membered ring. The OH radical $\left(x^{2} \pi\right)$ may be produced directly or may arise from the decomposition of HONO when its excess energy is

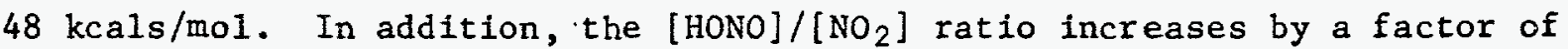
2 when the excitation wavelength goes from 222 to 308 nim : the elimination of HONO is in effect the most exothermic process [21].

$$
\underset{\mathrm{CH}_{3}}{\mathrm{CH}_{3}} \underset{\mathrm{CH}}{ }-\mathrm{NO}_{2} \stackrel{\mathrm{H \nu}}{\longrightarrow} \mathrm{C}_{3} \mathrm{H}_{6} \mathrm{NO}+\mathrm{OH}
$$
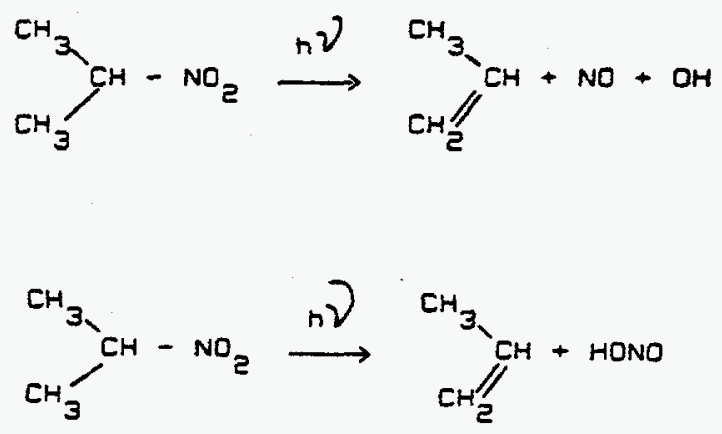

The quantum yield of $\mathrm{OH}$ formation at $266 \mathrm{~nm}$ is $(0.004 \pm 0.001)$ in the absence of collision [27], but at $282 \mathrm{~nm}$ the formation of $\mathrm{OH}$, which occurs efficiently in nitroethane, nitropropanes, and tert-nitrobutane, does not come into play in the case of nitromethane according to Greenblatt et al. [26], since the participation of a five-membered ring is necessary and proven by 
the formation of $\mathrm{OH}$ and not of $\mathrm{OD}$ from $\mathrm{CH}_{3} \mathrm{CD}_{2} \mathrm{NO}_{2}$. The quantum yields of formation are low, however $(0.5-2 \%)[26]$.

\subsubsection{Production of $\mathrm{CN}, \mathrm{C}_{2}, \mathrm{CH}$, and NO Fragments}

At high laser intensity, Haugen and Steinmetz demonstrated that $\mathrm{CN}, \mathrm{C}_{2}$, and $\mathrm{CH}$ fragments form in consecutive absorption processes at $193 \mathrm{~nm}$ [16], and the intermediate stages pass through $\mathrm{CH}_{2}$ or $\mathrm{CH}_{3}$ [22]. Under these high fluence conditions, No fragments are also observed [23].

\subsection{UV Photolysis of Nitromethane in the Condensed Phase}

Brown and Pimentel [28] showed that the photolysis of nitromethane in an argon matrix of $20 \mathrm{~K}$ yielded methyl nitrite by cage recombination of $\mathrm{CH}_{3}$ and $\mathrm{NO}_{2}$ fragments [3]. In the liquid phase as well, the main product is methyl nitrite [6, 29], and in a matrix of water or carbon tetrachloride at $77 \mathrm{~K}$, the EPR spectra of $\mathrm{NO}_{2}$ and $\mathrm{CH}_{3}$ were observed after photolysis of $\mathrm{CH}_{3} \mathrm{NO}_{2}$ [30]. The effect of oxygen on the yield of methyl nitrite was interpreted as proof of the existence of an excited state lasting long enough to react with the oxygen [29]. Nitrosomethane is also formed in significant proportions [29]. It is the result of secondary reactions:

$$
\begin{aligned}
& \mathrm{CH}_{3}+\mathrm{NO}_{2} \longrightarrow \mathrm{CH}_{3} \mathrm{ONO}^{*} \longrightarrow \mathrm{CH}_{3} \mathrm{O}+\mathrm{NO} \\
& \mathrm{CH}_{3}+\mathrm{NO} \longrightarrow \mathrm{CH}_{3} \mathrm{NO} \\
& \mathrm{CH}_{3}+\mathrm{CH}_{3} \mathrm{NO}_{2} \rightarrow \mathrm{CH}_{3} \mathrm{O}+\mathrm{CH}_{3} \mathrm{NO}
\end{aligned}
$$

Reaction (11), posed as an hypothesis by Cundall et al. [29], is considered 
by Tran-Dinh-Son and Sutton as playing a very important role [31]. These authors determined the quantum yield of ritromethane decomposition at $253.7 \mathrm{~nm}$-$\phi \geq(0.22 \pm 0.03)$ - f rom the quantum yields of formation of the main products, $\mathrm{CH}_{3} \mathrm{ONO}, \mathrm{HCHO}, \mathrm{CH}_{3} \mathrm{NO}, \mathrm{N}_{2}$, NO, and $\mathrm{N}_{2} \mathrm{O}$.

Faust et al. obtained an absorption spectrum in the picosecond laser photolysis of liquid nitromethane at $266 \mathrm{~nm}$; the increase in this spectrum had not stopped after 13 nanoseconds [32]. Although the effective absorption cross section of $\mathrm{NO}_{2}$ is low, these authors attributed the absorption to $\mathrm{NO}_{2}$, and they explained the formation kinetics by the existence of a precursor: the nitromethane triplet or an isomer such as the aci-form already proposed by Napier and Norrish [10].

Quite recently, another product -- nitrosomethanol $\mathrm{CH}_{2}(\mathrm{NO}) \mathrm{OH}$-- was detected by Jacox [33] using IR spectroscopy, in the photodecomposition of nitromethane in an argon matrix at $14 \mathrm{~K}$. Finally, Engel ke et al. [34] used ${ }^{13} \mathrm{C}-\mathrm{MMR}$ to show that the UV irradiation of nitromethane produces the aci-ion, while no detectable quantity of methyl nitrite was observed.

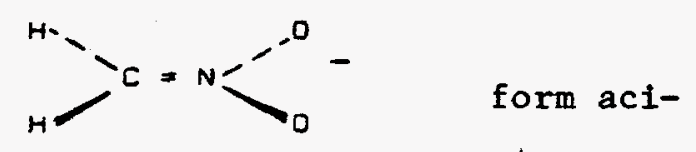

\subsection{UV Photolysis of Nitromethane in Solution}

The reactivity of nitroalkanes excited in WV light is modified a little in dilute solution. In solvents which readily give up a hydrogen, such as alcohols, $\mathrm{RNO}_{2} \mathrm{H} \cdot$ radicals are produced in Reaction (12) [35, 36]:

$$
\mathrm{RNO}_{2}^{*}+\mathrm{R} \cdot \mathrm{H} \longrightarrow \mathrm{RNO}_{z^{H}}+\mathrm{R}
$$


In aqueous solution, the photolysis of nitromethane or nitroethane gives the EPR spectrum of the $\mathrm{RNO}_{2}{ }^{-}$radical anion, but this spectrum is more intense in a basic medium, necessary for neutralizing the conjugated acid $\mathrm{RiNO}_{2} \mathrm{H}$ [37]. In cyclohexane also, the excited $\mathrm{NO}_{2}$ * group takes a hydrogen from the solvent [38, 39]. Jarosiewiez et al. [40], however, believe that this process is negligible $\left(\phi=c a \cdot 10^{-2}\right)$ in comparison with the cleavage of the $\mathrm{C}-\mathrm{N}$ bond. The role of the solvent is nonetheless important, since its polarity and its polarizability are manifested in the cage effect which leads to the recombination of the $\mathrm{CH}_{3}$ and $\mathrm{NO}_{2}$ radicals, in competition with the creation of stable products [40]. In solution, the quantum yield of $\mathrm{CH}_{3} \mathrm{NO}_{2}$ photodecomposition should therefore be less than in the gas phase [40].

\subsection{Mu1tiphotonic Photolysis in Infrared Light, in the Gas Phase}

With the development of lasers delivering high luminous intensities in the infrared region, many IR photolysis experiments were done. They showed that the molecules could dissociate in the absence of collision, after having stored the vibration energy by absorbing a large number of IR photons. In the case of nitromethane gas, $\mathrm{NO}_{2}, \mathrm{CH}, \mathrm{CN}, \mathrm{C}_{2}, \mathrm{OH}, \mathrm{O}_{2}$, and $\mathrm{NH}$ fragments were observed in fluorescence after excitation of the $v_{7}\left(921 \mathrm{~cm}^{-1}\right)$ and $v_{13} \operatorname{modes}$ $\left(1097 \mathrm{~cm}^{-1}\right)[41-44]:$

$$
\begin{aligned}
& \nabla_{7}[Q(C-N), \gamma(O N D)] \\
& \nu_{13}[\alpha(H C H), B(H C N)]
\end{aligned}
$$

The multiphotonic IR dissociation of $\mathrm{CH}_{3} \mathrm{NO}_{2}$ produces $\mathrm{NO}_{2}$ fragments in the fundamental electronic state which Avouris et al. [44] analyzed in laserinduced fluorescence (LIF). But they also observed the direct fluorescence of electronically excited $\mathrm{NO}_{2}$ * fragments resulting from a vibration-electronic 
energy transfer $(V+E)$ [44]. According to these authors, CN* fragments could be produced from a very organized excited state of $\mathrm{CH}_{3} \mathrm{NO}_{2}$ in Reaction (13):

$$
\mathrm{CH}_{3} \mathrm{NO}_{2} \stackrel{\mathrm{nn} \mathrm{D}}{\longrightarrow} \mathrm{CN}+\mathrm{H}_{2} \mathrm{O}+\mathrm{OH}
$$

or from a sequential excitation with the intermediate $\mathrm{CH}_{3} \mathrm{NO}$ resulting from the cleavage of an No bond $(72 \mathrm{kcals} / \mathrm{mol})$. $\mathrm{CH} *$ and $\mathrm{C}_{2}$ * fragments result from bimolecular reactions [44]. Another method of analyzing the $\mathrm{NO}_{2}$ and $\mathrm{CH}_{3}$ fragments is multiphotonic ionization spectroscopy of the $\mathrm{NO}_{2}$, which proves their rotational excitation $[45,46]$. Rockney and Grand thus concluded that the relaxation leads to a high translation energy of the fragments [46]. Quite recently, Wodtke et al. also observed $\mathrm{CH}_{3} \mathrm{O}$ and NO fragments arising from the dissociation of the very hot isomer $\mathrm{CH}_{3}$ ONO of nitromethane, obtained by multiphotonic IR excitation in a molecular jet $[47,48]$. These authors measured the flight times [sic; lifetimes? -- Tr. Ed.] of the ions coming from the species $\mathrm{NO}_{2}, \mathrm{CH}_{3}$, NO, and $\mathrm{CH}_{3} \mathrm{O}$, which they Ionized by electron impact. They thus determined the translation energy probability distribution of these fragments. For $\mathrm{CH}_{3}$ and $\mathrm{NO}_{2}$, the results show that there is a simple cleavage without any exit energy barrier, and a low translation energy. With respect to the NO fragment, the results showed that two reaction pathways are involved: Reaction (1), since the ionization of $\mathrm{NO}_{2}$ leads to the $\mathrm{NO}^{+}$ion, and Reaction (14) of nitromethane isomerization, followed by dissociation (15) of the methyl nitrite, whose internal energy is sufficient:

$$
\mathrm{CH}_{3} \mathrm{NO}_{2} \underset{\mathrm{IR}}{\stackrel{\mathrm{nn} \mathcal{\nu}}{\longrightarrow}} \mathrm{CH}_{3} \mathrm{ONO}
$$




$$
\mathrm{CH}_{3} \mathrm{ONO}^{*} \longrightarrow \mathrm{CH}_{3} \mathrm{O}+\mathrm{NO}
$$

The peak of the $\mathrm{HCO}^{+}$ion coming from the $\mathrm{CH}_{3} \mathrm{O}$ fragment shows that this latter has a high translation energy, which these authors explained by the reaction pathway (14)-(15). The branching ratio of Reactions (1) and (14) is $k_{14} / k_{1}=0.6$, in favor of (1). For nitroethane, they showed that in competition with Reaction (1), Reaction (4), whose activation energy is $45 \mathrm{kcals} / \mathrm{mol}$, liberates a strong translation energy from the products $\mathrm{C}_{2} \mathrm{H}_{4}$ and HONO. For 2-nitropropane, they arrived at the same conclusion, i.e., the existence of Reaction (8), and the branching ratio of Reactions (1) and (8) is $k_{8} / k_{1}=0.5$, in favor of the $\mathrm{C}-\mathrm{N}$ cleavage.

Wodtke et al. calculated the energy of the potential barrier of the process of $\mathrm{CH}_{3} \mathrm{NO}_{2}$ isomerization; it is between 51.5 and $55.5 \mathrm{kcals} / \mathrm{mol}$. The energy of the barrier for the process of HONO elimination is $(46 \pm 1.5)$ kcals/mol for nitroethane, and 3-5 kcals/mol lower for 2-nitropropane. In these two compounds, they noted the absence of the process of isomerization and formation of alkoxy radicals and No [48].

The multiphotonic IR ionization of nitromethane is also possible, but it requires a much higher energy $(11.3 \mathrm{eV})$ than that needed for dissociation [49].

\section{KINETICS OF DISSOCIATION OF THE C-N BOND}

Rockney et al. [46] calculated that it would take 20 photons at $9.6 \mu \mathrm{m}$ ( $\mathrm{R}(20)$ ray of the $\mathrm{CO}_{2}$ laser), at an energy of $3.08 \mathrm{kcals} / \mathrm{mol}$, to bring a molecule of $\mathrm{CH}_{3} \mathrm{NO}_{2}$ above the threshold of dissociation $\left(E_{0}=58.8 \mathrm{kcals} / \mathrm{mol}\right)$. The RRKM theory makes it possible to calculate the rate of dissociation of a 
molecule excited above the threshold of dissociation $E_{\rho}$. Measurement of the dissociation times between 1 and 100 nanoseconds gives the rate constant of dissociation $k\left(E^{*}\right)$, which makes it possible to deduce the excess energy $E^{*}$ and then the energy $\left(E^{*}-E_{0}\right)$ which will be distributed in the degrees of freedom of the fragments. In the RRKM theory, the model takes into account the "activated complex" or "critical molecular configuration". Rockney et al. thus found 14 vibration frequencies -- those of $\mathrm{CH}_{3} \mathrm{NO}_{2}$, among which the C-N elongation vibration disappears and six other vibrations are weakened. They obtained an Arrhenius constant of $A=1.5 \times 10^{16} \mathrm{sec}^{-1}$ at $900 \mathrm{~K}$ and $1.9 \times 10^{16} \mathrm{sec}^{-1}$ at $1,400 \mathrm{~K}$. The RRKM rate constants which they calculated for 1-4 excess IR photons are given in Table 2 [46].

TABLE 2. RATE CONSTANTS AND LIFETIMES CALCULATED FOR THE DISSOCIATION OF $\mathrm{CH}_{3} \mathrm{NO}_{2}$, AS A FUNCTION OF THE EXCESS ENERGY ABOVE THE DISSOCIATION THRESHOLD. KEY: (a) excess energy, $\mathrm{cm}^{-1}$; (b) rate constant, $\mathrm{sec}^{-1}$; and (c) lifetime, sec.

\begin{tabular}{|c|c|c|c|}
\hline $\begin{array}{c}\text { Energiejen exces } \\
\text { (am }\end{array}$ & $\begin{array}{c}\text { Constante de vitesse } \\
\text { (a) (b) }\end{array}$ & $\begin{array}{c}\text { Duree de vie } \\
\text { (5) (c) }\end{array}$ & Reference \\
\hline 979 & $1,66 \times 10^{7}$ & $6,03 \times 10^{-9}$ & {$[46]$} \\
2057 & $1,71 \times 10^{-9}$ & $5,85 \times 10^{-9}$ & {$[46]$} \\
3154 & $8,82 \times 10^{8}$ & $1,13 \times 10^{-9}$ & {$[46]$} \\
4211 & $3,16 \times 10^{9}$ & $3,16 \times 10^{-10}$ & {$[46]$} \\
7695 & $3,3 \times 10^{10}$ & $3,0 \times 10^{-11}$ & {$[48]$} \\
16813 & $4,8 \times 10^{12}$ & $2,1 \times 10^{-13}$ & {$[25]$} \\
\hline
\end{tabular}

Forst's approach, on the other hand, does not require knowing the vibration frequencies of the reactant $\mathrm{CH}_{3} \mathrm{NO}_{2}$, nor those of the transition state [51]. Mialocq and Stephenson also used the Forst equation

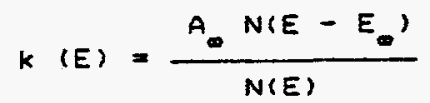


where $A_{\infty}$ and $E_{\infty}$ are the Arrhenius parameter and activation energy, and $N(E)$ and $N\left(E-E_{\infty}\right)$ are the densities of state of the reactant, which can be calculated from the vibration frequencies according to the Whitten-Rabinovitch method. With $A_{\infty}=1.78 \times 10^{16} \mathrm{sec}^{-1}, E=37,594 \mathrm{~cm}^{-1}$, and $E_{\infty}=20,778 \mathrm{~cm}^{-1}$,

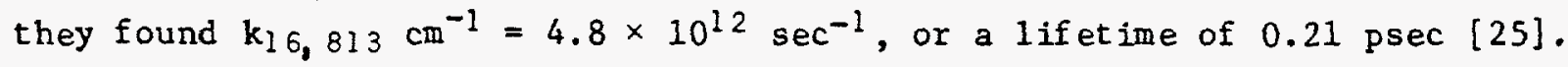
The value of $A_{\infty}$ is subject to argument, however, since the excitation energy is greatly over the threshold. The RRKM calculation done by Wodtke et al. [48] gives a lifetime of $30 \mathrm{psec}$ for an excess energy of $7695 \mathrm{~cm}^{-1}$. These latter values are also shown in Table 2, for comparison. We see that the values calculated by Mialocq and Stephenson for a monophotonic luminous excitation at $266 \mathrm{~nm}$ are in good agreement with the kinetics of formation of the $\mathrm{NO}_{2}$ fragment $[18,25]$.

\section{THOUGHTS ON THE INITIATION OF NITROMETHANE DETONATION}

Nitromethane is a rocket fuel which detonates under the effect of a shock wave [53,54], and a less powerful explosive than the nitroethers, but its greater chemical stability is an advantage [55]. Its critical detonation diameter is $12-20 \mathrm{~mm}$ and the initiation pressure for detonation is on the order of 90 kbars [55]. The capacity for detonation is increased by the addition of inorganic acids, water, organic bases, and di- and triethylamines [55-58]. For example, Kondrikov et a1. [55] noted that $0.025 \%$ of amine was enough to cut the critical diameter to half its initial value. UV 1 ight also contributes to the sensitivity of nitromethane $[34,57-58]$.

A number of authors have therefore suggested that the basic anionic species $\mathrm{CH}_{2} \mathrm{NO}_{2}^{-}$[57-58] and the protonated species $\mathrm{CH}_{2} \mathrm{NO}_{2} \mathrm{H}$ [59] were the initial species causing the detonation sensitization. According to Engelke et al. 
[57], the detonation rate of nitromethane is proportional to the concentration of the anionic form (aci-ion). Considering that the pressure increases the autoionization of weak acids, they calculated that at 50 kbars and $400 \mathrm{~K}$, the concentration of $\mathrm{CH}_{2} \mathrm{NO}_{2}{ }^{-}$was multiplied by 80 in comparison to normal conditions, and they rejected even the hypothesis that the initial species of liquid nitromethane chemistry under the effect of a shock wave were radicals.

In aqueous solution, the $\mathrm{pK}$ a $\mathrm{CH}_{3} \mathrm{NO}_{2}$ is 10.2 at $25^{\circ} \mathrm{C}$, and the $\mathrm{CH}_{2} \mathrm{NO}_{2}{ }^{-}$ anion which is isoelectronic with the nitramine $\mathrm{H}_{2} \mathrm{~N}-\mathrm{NO}_{2}$ shows an absorption band at $233 \mathrm{~nm}$ which suggests intramolecular charge transfer between the $\mathrm{CH}_{2}{ }^{-}$electron donor group and the $\mathrm{NO}_{2}$ electron acceptor group. These two groups are represented in the nonplanar form of the molecule, which is less stable than the planar form with the double bond [61]:
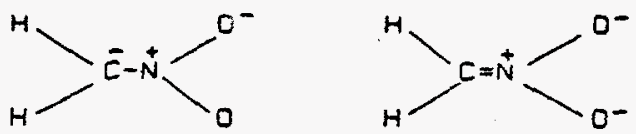

The initiation of detonation in solid nitromethane probably involves a multiphonon excitation of the internal vibrations of the molecule [62], and according to Peyrard et al. $[62,63]$, the $\mathrm{C}-\mathrm{N}$ cleavage propagates in a cooperative mechanism.

With respect to theory, recent calculations are in favor of a rearrangement of the nitromethane into methyl nitrite, the dissociation of which is easier [64]. At $700^{\circ} \mathrm{C}$, this rearrangement predominates over the $\mathrm{C}-\mathrm{N}$ cleavage, which will become predominant only at a higher temperature [64]. A quantum mechanical study of the $\mathrm{C}-\mathrm{N}$ cleavage has just shown the existence of resonances and high oscillations of the photofragmentation rate as a function of the total energy [65]. 
It is still too early, however, to say that one or more of the unimolecular Reactions (1), (3), (4), (5), (6), (7), (8), or (9) constitute the initial stages of the ignition of nitromethane subjected to a shock wave, since a very fast bimolecular reaction has just been proposed by Bardo [66] as the initial step. It is a head-to-tail reaction

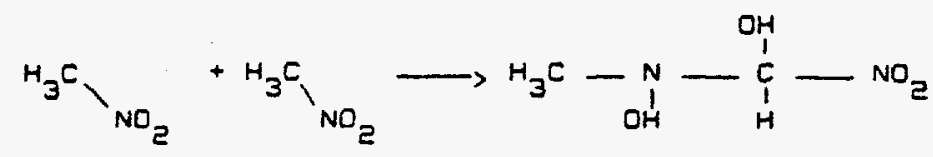

for which the half-reaction time would be $5 \times 10^{-12} \mathrm{sec}$ at a pressure of 80 kbars and a temperature of $850 \mathrm{k}$. While the writing of this particular reaction is difficult to justify, the hypothesis of a fast bimolecular reaction involving $\mathrm{a} \mathrm{CH}_{2} \mathrm{NO}_{2}^{-}$anion seems plausible in the condensed phase.

\section{UV PHOTODECOMPOSITION OF NITRAMINES}

The study of the photodecomposition of nitramines is motivated by their use as rocket fuels and explosives, such as $\operatorname{HMX}$ and $\mathrm{RDX}$ [67]. An essential characteristic is the cleavage of the $\mathrm{N}-\mathrm{N}$ bond, the bond energy of which is 46.2 kcals/mol; it is thus easier than the C-N cleavage [68]. Recently, Mialocq and Stephenson [69] showed that the photodissociation of dimethylnitramine at $266 \mathrm{~nm}$ was accomplished in less than $6 \mathrm{psec}$, with a high quantum yield on the order of 0.48 [25]. A high proportion of electronically excited $\mathrm{NO}_{2}$ * fragments is also formed, with a quantum yield of $0.06[25,69]$.

$$
\left(\mathrm{CH}^{3}\right)^{5} \mathrm{NNO}^{5} \frac{5 \mathrm{nN}}{\mathrm{hm}}\left(\mathrm{CH}^{3}\right)^{5} \mathrm{~N}+\mathrm{NO}^{5}
$$

The rapid formation of $\mathrm{NO}_{2}$ in the case of dimethylnitramine is in agreement with the calculation of the rate constant of unimolecular dissociation 
according to Forst's approach: $k=2.5 \times 10^{11} \mathrm{sec}{ }^{1}$, or $\tau=$ ca. 4 sec [25]. Likewise, the picosecond laser excitation at $266 \mathrm{~nm}$ of a solution of tetryl in methanol showed the appearance in the laser pulse of a strong absorption in the visible region of the spectrum, which could be that of the $\mathrm{N}$-methyltrinitroanilino radical resulting from $\mathrm{N}-\mathrm{NO}_{2}$ cleavage [70].

\section{CONCLUSION}

The monophotonic UV or multiphotonic IR photodissociation of nitro substances is a very fast process which occurs in less than 6 picoseconds in the case of nitromethane and dimethylnitramine in the gas phase. The cleavage of the $\mathrm{C}-\mathrm{NO}_{2}$ or $\mathrm{N}-\mathrm{NO}_{2}$ bonds is not necessarily the primary step in the initiation of the detonation of nitro explosives in the liquid or crystalline phase. Intramolecular rearrangement reactions may be involved as well, as may bimolecular reactions. Additional studies are under way to clarify the mechanism of photodissociation of nitromethane and tetryl in the condensed phase. 
[1] HIRSEHLAFF, E. et NORRISH, R.G.W., J. Chem. Soe. (1936) 1590.

[2] CHOW, Y.L. dans The Chemistry of amino, nitroso and nitro compounds and their derivatives, Part 1, Saul Patai, editeur (John Wiley \& Sons) 181 (1982).

[3] PIMENTEL, G.C. et ROLLEFSON, G., Eite dans Formation and Trapping of Free Radicals, A.M. Bass et H.P. Broida, editeurs (Academil Press) Cnapitre 4, 97 (1960).

[4] COTTRELL, T.L et REID, T.J., J. Chem. Phys., 18 (1950) 1306.

[5] NICHOLSON, A.J.C., Nature $190(1961) 143$.

[b] RebBert, R.e. et Slage, N., Buld. Soc. Chim. Belg. 71 (1962) 709 .

[7] Me GaRVEY, J.J. et ME GRaTh, W.D., Trans. Far. Soc. b0 (1964) 2196.

(8) CHRISTIE, M.I., GILLBERT, C. et VOISEY, M.A.. J. Chem. Soc. (1964) 3147 .

[9] PASZYC, S., Photochem. Photobiol. 4 (1965) 841.

[10] NAPIER, I.M. et NORRISH, R.G.W., Proc. ROY. SOS. A, 299 (1967) 317.

[11] HONDA, K... MIKUNI, H. et TAKAHASI, M., Bul1. Chem. Soc. Jap., 45 (1972) 3534 .

[12] COLLES, M.J., ANGUS, A.M., MARINERO, E.E., Nature 262 (1976) 681 .

[13] MARINERO, E.E., COLLES, M.J.. PFAB, J.. dans Lasers in Chemistry, M.A. West, editeur (Elsevier) 170 11977).

[14] SPEARS, K.G. et BRUGGe, S.P., Chen. Phys. Lett. $54(1978) 373$. [15] BRUGGE, S.P., Dissert. Austracts 42, 9 (1982) 3702.

[16] MAUGEN, G.R. et STEINMETZ, L.L., Molecular Photochemistry? $(1979) 473$.

[17] KWOK, H.S., HE, G.Z., SPARKS, R.K. et LEE, Y.T., International Journal of Chemical Kinetics 13 (1981) 1125.

[18] SCHOEN, P.E., MARRONE, M.J., SCHNUR, J.M., GOLDBERG, L.S., Chem. Phys. Lett. 90 (1982) 272.

[19] BLAI5, N.C., J. Chem. Phys. 79 (1983) 1723.

[2O] BUTLER, L.J., KRAJNOVICH, D., LEE, Y.T., ONDREY, G. et BERSOHN, R., J. ChEm. PhYS. 79 (1983) 1708.

[21] RADHAKRISHNAN, G., PAAR, T. et WITTIG, C., Chem. Phys. Lett. 111 (1984) 25.

[22] NAGATA, T., SUZUKI, M., SUZUKI, K., KONDOW, T. et KUCHITSU, K., Chem. Phys. $88(1984) 163$.

[23] RENLUND, A.M. et TROTT, W.M., Chem. Phys. Lett. 107 (1984) 555 .

[24] MIALOCO, J.C. et STEPHENSON, J.C., dans Ultrafast Phenomena $V$. Springer Series in Chemical Physics 46. G.R. Fleming et A.E. Siegman, editeurs (Springer Verlag) 362 (1986). 
[25] MIALOCO, J.C. Et STEPHENSON, J.C., Chem. PhYs. 106 (1986) 281.

[26] GREENBLATT, G.D., ZUCKERMANN, H. et HASS, Y., Chem. Phys.

Lett. 134 (1987) 593.

[273 ZABARNICK, 5.S., FLEMING, J.W., BARONAVSKI, A.P. et LIN, M.C., NBS Spec. Publ. (U.S) 716 (1986) 731 .

[29] BROWN, H.W. et PIMENTEL, G.C., J. ChEm. Phys. 29 (1958) B83.

[29] CUNDALL, R.B., LOCKE, A.W. et STREET, G.C., dans The Chemistry of Ionization and Excitation. G.R.A. Johnson et G. Seholes, editeurs (Taylor \& Franeis, Lto) 131 (1967).

[30] BIELSKI, B.H.J. et TIMMONS, R.8., J. Phys. Chem. 68 (1964) 347.

[31] TRAN DINH SON et SUTTON, J., Int. J. Radiat. Phys. Chem. 5 (1973) 149 .

[32] FAUST, W.L., GOLDBERG, L.S., ROYT, T.R., BRADFORD, J.N., WILLIAMS, R.T. et SCHNUR, J.M., dans Picosecond Phenomena. Springer Series in Chemical Physics 4 p.43 (2978).

[33\} JACOX, M.E., J. Phys. Chem 88 (1984) 3373.

[34] ENGELKE, R., EARL, W.L. et ME MICHAEL ROHLFING, C., J. PhYS. Enem. 90 (1986) 545 .

[35] CHACHATY, C., FORCHIONI, A., Tetrahedron Letters 9 (1968) 1079

[36] CHACHATY, C., FORCHIONI, A., J. Chim. Phys. 65 (1968) 1649

[37] ZELDES, H. et LIVINGSTON, R., JACS $90(1968) 4540$

[38] REID, S.T. et WILCOX, E.J., Tetranedron Letters $18(1972) 1759$

[39] REID. S.T., TUCKER, J.N. et WILCOX, E.J., J.C.S. Perkin I. (1974) 1359

[40] JAROSIEWICZ, M., SZYCHLINSKI, J. et PISZCZEK, L., J. Photochenistry 29 11985, 343

[41] AMBARTZUMIAN, R.V., CHEKALIN, N.V., LETOKHOV, V.S. Et RYABOV, E.A., Chem. Phys. Lett. 36 (1975) 301

[42] CHEKALIN, N.V., DOLZHIKOV, V.S., KOLOMIYSKY, YU.R., LOKHMAN, V.N., LETOKHOV, V.S. et RYABOV, E.A. PhYS. Lett. 59A (1976) 243

[43] CHEKALIN, N.V., DOLZHIKDV, V.S., KDLOMIYSKY, YU.R., LETOKHOV, V.S., LOKHMAN, V.N. et RYABOV, E.A., Appl. Phys. 13 (1977) 311

[44] AVOURIS, P., CHAN, I.Y. Et LOY, M.M.T., J. Photochem. 13 (1980) 13

[45] ROCKNEY, B.H. et GRANT, E.R., Chem. PHYS. Lett. 79 (1981) is

[46] ROCKNEY, B.H. et GRANT, E.R., J. Chem. PhYs. 79 (1983) 708

[47] WODTKE, A.M., HINTSA, E.J. et LEE, Y.T., J. Chem. PhyS. 84 (1986) 1044

[48] WODTKE, A.M., HINTSA, E.J. et LEE, Y.T., J. PhYS. Chem 90 (1986) 3549

[49] AVOURIS, P., CHAN, I.Y. et LOY, M.M.T., J. Chem. Phys. 70 (1979) 5315 
[50] Unimolecular Reactions, P.J. Robinson, K. A. Holorook, editeurs (wiley Interscience), Chapitres 4 et 5 (1972)

[51] FORST, W., J. PhYS. Cham. 76 .1972) 342

[SE] TRINQUECOSTE, C., REY-LAFON, M. et FOREL, M.T., Spectrochimica Acta $30 A(1974) 813$

[53] MAKOVKY, A. et LENJI, L., Chem. ReV. 58 (1958) b27

[54] CHIRAT, R. et PITTION-ROSSILLON, G., Combust. Flame 45 (1982) 147

[SS] KONDRIKDV, B.N., KOZAK, G.D., RAIKDVA, V.M. Et STARSHINOV, A.V., Doklady Physical Chemistry 233 (1977) 315

[56] 3RASCH, J.W. J. Phys. Chem. B4 (1980) 2084

[S7] ENGELKE, R., EARL, W.L. et ME MICHAEL ROHLFING, C., J. ChEm. Phys. 84 (1986) 142

[SE] ENGELKE, R., EARL, w.L. et MC MICHAEL ROHLFING, C., Int. J. Chem. Kin $18(1986) 1205$

[593 Ref. 7-10 dans la reference 57

[oO] NAGAKURA, S., Molecular PAYsies 3 (1960) ise

[G1] MURRELL, J.N., VIDAL, B. et GUEST, M.F., J. Chem. Soc. Farad Trans. I1, $71(1975) 1577$

[Gí] PEYRARD, M., ODIOT, S., LAVENIR, E. et SCHNUR, J.M., J. App]. Phys. 57 (1985) 2626

[63] PEYRARD, M., DDIOT, S., ORAN, E., BORIS, J. et SCHNUP, J., Phys. Rev. B 33 (1986) 2350

[(M] DEWAR, M.J.S., RITCHIE, J.P. et ALSTER, J., J. OTg. Cham. SO (1985) 1031

[ES] PERNOT, P.. ATABEK, O., BESWICK. J.A. Et MILLIE. Ph., J. PhyS. Chen. $91(1997) 1397$

[.bb] BARDD, R.D., dans Shock Waves in Condensed Matter, Y.M. Gupta, editeur (Plenum Press) 843 (1986)

[67] FIFER, R.A.. Prog. Astronautics Aeronautiss 90 (1994) 177

[68] SHAW, R. et WALKER, F.E., J. Phys. Chem. 81 (1977) 2572

[69) MIALOCQ, J.C. et STEPHENSON, J.C., Chem. Phys. Lett. 123 (1986) 390

[70] CRAIG, B.B., CHATTOPADYAY, S.K. et MIALDCQ, J.C., dans Ultrafast Phenomena. V. Springer Serjes in Chemical Phrsics 46. G.R. Fleming et A.E. Siegman, editeurs (Springer Verlag) 334 (1986)

KEY : dans = in; et = and; editeurs = editors; cité dans = cited in. 